\title{
Reports of the EASD Study Groups 1989/1990
}

\section{European Association for the Study of Diabetes, Diabetic Pregnancy Study Group}

\author{
Officers: Chair: R. De Hertogh \\ Committee Members: $\quad$ L.Mölsted-Pedersen \\ U.Ericksson
}

Total Membership in Study Group: 29 full members, 15 honorary members

Last Meeting: 21st Annual Meeting, August 31-September 3 1989, Uppsala, Sweden

The meeting was held in a castle (Wik Slot), a few miles from Uppsala. The host was Prof. C. Hellerström. About 80 members, guests and invited speakers attended the seven sessions, covering the following topics:

1. Perinatal outcome (1 session)

2. Embryogenesis and Teratogenesis ( 3 sessions)

3. Follow-up of mothers ( 1 session)

4. Recent advances in diabetic pregnancy ( 1 session)

5. Long-term follow up of progeny ( 1 session)

Key-notes were given by:

- S.Hunter: Embryogenesis and cell differentiation

- A.Goldman: Mechanisms and prevention of the diabetic embryopathy

- N.Freinkel: The 1989 status of the hypothesis: "Fuel mediated teratogenesis"

- M. Lorenzi: A cellular model of glucose toxicity

The Jorgen Pedersen lecture was given by J. Roth on: "Intercellular communication in the early embryo: possible participation of insulin and insulin-like growth factors and their receptors".

Members and guests contributed with 38 papers to the different sessions.

Next Meeting: 22nd Annual Meeting September 27-30, 1990, Toledo - Spain

Details available from: Dr. R. De Hertogh

University of Louvain

Endocrinology and Nutrition

U.C.L. 5330

Av. E. Mounier 53

1200 Bruxelles

Belgium

\section{European Association for the Study of Diabetes, Lipoprotein Study Group}

\section{Aims}

The aim of this study group is to promote the research of serum lipids, lipoproteins and atherosclerosis in diabetes, to emphasize the importance of the recognition and treatment of hyperlipidemias in diabetes and to encourage relevant surveys and clinical trials. In pursuit of these aims the study group will meet once per year.

\section{Membership}

Membership of this study group will be open to persons actively involved in the research of these areas or in the treatment of hyperlipidemic diabetics and of any others whom the Committee and its officers should agree upon.

\section{Committee and its Officers}

The Committee will consist of a Chairman, a Vice-chairman and a Secretary with three additional ordinary Members. The President of EASD, or his nominated deputy, is a member ex-officio. All will be elected by a simple majority of Group Members attending an Annual Meeting.

Officers shall serve in the same or lesser post for a maximum of three years and be re-eligible to serve after a lapse of one year. They may be selected from the total Group membership, including Committee members. Ordinary Committee Members shall serve for three years but are eligible (as are the Officers) for a further three year term without break to serve in a higher position. The Committee shall have power to co-opt additional members for up to three years.

\section{Meetings}

The Committee shall meet at least once a year. Decisions may be taken by correspondence. All Group Members, advised by the Committee and Officers, will select the venue and themes for future meetings. Final programme selection will be made by the Officers in collaboration with a host member. Organisation of the meeting and its funding will be the joint responsibility of the host members assisted by the Officers, Committee and Group Members as appropriate.

Preliminary Programm

Lipoprotein Study Group Meeting, EASD

September 9th, Steno Memorial Hospital, Copenhagen

14.00-14.30 Epidemiology of dyslipidemia in diabetes.

Markku Laakso, Kuopio.

14.30-14.45 Discussion

14.45-15.15 VLDL compositional changes in diabetics in relation to glucose control.

R. W. James, Geneva.

15.15-15.30 Discussion

15.30-16.00 Lipoprotein metabolic disturbances in diabetes. M. R. Taskinen, Helsinki

16.00-16.15 Discussion

16.15-16.30 Coffee

16.30-17.15 Treatment of diabetic dyslipidemias. Roundtable. M. R. Taskinen, Chairmann, Helsinki D. W. Erkelens, Utrecht, B.O.H. Vessby, Uppsala

17.15 Business Meeting. Future activities. Board

European Association for the Study of Diabetes, European Diabetic Nephropathy Study Group

Officers: Chair: C.E.Mogensen, M.D.

Vice Chair: Romano Nosadini, M.D.

Secretary: Jens Sandahl Christiansen, M.D.

Treasurer: Michel Marre, M.D.

President

Vice President

Secretary

Treasurer

retires 1993 retires 1993 retires 1991 retires 1993

Committee Members: Jean Jaques Altman, M.D. retires 1993 Daniel Carvalho-Braga, M.D. retires 1993 A. Ekstrand, M.D. retires 1993 Bo Feldt-Rasmussen, M.D. retires 1993 Renzo Navalesi, M.D. 


\section{Total Membership in Study Group: 80}

Last Meeting: Workshop on hypertension, epidemiology, and pathophysiology of kidney disease in type 2 diabetes, May 11-12, 1990, London, U.K.

The third meeting in the study group was arranged as a workshop in Stoke Poges outside London, UK. It was held May 11-12, 1990, with approximately 80 attendants. During three half day sessions 33 papers were presented within different fields of science related to kidney disease in diabetes.

The following topics were discussed:

1) Blood pressure and ischemic heart disease in NIDDM - discussing as well methodological problems in blood pressure measurements as renal hemodynamics in NIDDM and microalbuminuria as a predictor of mortality.

2) Proteinuria, lipids and glomerulopathy in type 1 and type 2 diabetes - including prevalence and causes of albuminuria in NIDDM as well as prevalence data of hyperlipidemia in IDDM.

3) Sodium lithium counter transport in diabetes. A number of different experimental studies relating this phenomenon to kidney function was presented. Presently there is no agreement whether sodium lithium counter transport represents a predictive parameter or is a secondary phenomenon.

4) Hormonal factors and renal function in diabetes - discussing the interrelationship between insulin and the angiotensin system, noradrenaline and dopamine. Also insulin like growth factors and atrial natriuretic peptide related problems were discussed.

5) Clinical nephropathy in type 1 diabetes. Studies dealing with biosynthesis of glycosamino glycans, left ventricular hypertrophy, non-glycated albumin, as well as prevalence data, were discussed. In addition the effect of early antihypertensive treatment was addressed.

Next Meeting: Angers, France, May 10-11,1991

Details available from: J.Sandahl Christiansen

Medical Department M.

Kommunehospitalet

DK-8000 Aarhus C

Denmark

\section{European Association for the Study of Diabetes, Diabetes and Nutrition Study Group}

\begin{tabular}{|c|c|c|c|c|}
\hline fficers: & $\begin{array}{l}\text { Chair: } \\
\text { Vice chair: } \\
\text { Secretary: }\end{array}$ & $\begin{array}{l}\text { M. Toller } \\
\text { I. De Leeuw } \\
\text { G. Riccardi }\end{array}$ & $\begin{array}{l}\text { F.R. Germany } \\
\text { Belgium } \\
\text { Italy }\end{array}$ & $\begin{array}{l}\text { retires } 1992 \\
\text { retires } 1992 \\
\text { retires } 1990\end{array}$ \\
\hline$m m i$ & ers & $\begin{array}{l}\text { R. Heine } \\
\text { B. Karamanos } \\
\text { B. Karlstrom } \\
\text { M.Lean } \\
\text { P. Robertson } \\
\text { G. Slama }\end{array}$ & $\begin{array}{l}\text { The Netherlan } \\
\text { Greece } \\
\text { Sweden } \\
\text { G. Britain } \\
\text { Norway } \\
\text { France }\end{array}$ & $\begin{array}{l}\text { s retires } 1992 \\
\text { retires } 1992 \\
\text { retires } 1991 \\
\text { retires } 1992 \\
\text { retires } 1991 \\
\text { retires } 1991\end{array}$ \\
\hline
\end{tabular}

Total Membership in Study Group: 51

Last Meeting: 7th International Symposium on Diabetes and Nutrition June 28-301989 Bussum. The Netherlands

\section{Attendance: 42 Physicians, nutritionists, biochemists, dietitians}

Subjects discussed: Postprandial glucose control: artificial sweeteners and/or low glycaemic foods. Dietary proteins in relation to serum lipids and kidney function. Dietary advice: assessment of compliance and metabolic efficacy. Dietary treatment in relation to diabetes and obesity.

At the business meeting the following regulations of the study group were approved.

Next Meeting: 8th International Symposium on Diabetes and Nutrition Dubrovnik Yugoslavia June 27-29, 1990
Details available from: Prof. Dr. Izet Aganovic

Inst. of Endocrinology

Zagreb University School of Medicine

Kispaticeva 12

YU-41000 Zagreb

Yugoslavia

\section{European Association for the Study of Diabetes, Regulations of the Diabetes and Nutrition}

1. The study group shall be known as the Diabetes and Nutrition Study Group. It may also be referred to be the initials DNSG.

2. Aims of the DNSG are to promote a) scientific interchange on clinical and metabolic effects of nutrition in relation to diabetes; $b$ ) implementation of appropriate dietary therapy in individuals with diabetes.

3. The DNSG shall normally meet on an annual basis for a scientific symposium. The time and place of such meetings will be decided by the committee of the group. The business meeting of the DNSG will normally coincide with the scientific meeting. A vote can be taken at the business meeting only if $50 \%$ of members are present.

4. Membership in the DNSG is open to all interested persons regardless of whether they are members of EASD or not. However, the officers of the study group are required to be paid-up members of EASD. In order to become a member of DNSG an application, together with a short curriculum vitae, has to be forwarded to the executive committee after the candidate has presented a paper at a scientific meeting of the group on at least two occasions. The committee will propose the new members at the next business meeting of the group where the final decision will be taken. Membership will terminate in the case of absence at three consecutive scientific meetings of the study group. The committee may propose honorary members, who shall be approved by the General Assembly.

5. Members of DNSG are entitled a) to participate and to vote in the business meeting of the study group; b) to elect the committee.

6. Meetings of the study group shall be open to all interested persons. Priority will be given to members and others presenting papers. Advertisment of the meeting shall be placed each year in Diabetologia.

7. The committee of DNSG consists of 9 members elected by the members present at the business meeting of the group. They are elected for 3 years and may be re-elected at the end of their term if they have been selected as office-bearer. The 3 office-bearers (chairman, vice-chairman and secretary) will be chosen by the elected committee from amongst their number. The names will be submitted to the business meeting for approval. If a majority of those present does not approve a nominated office-bearer, an election may be held. Any other member of the elected committee may be nominated provided he/she is supported by three members of the group and agrees in writing to stand for election. Committee members may serve consecutively in different offices, but will normally not serve for more than 3 consecutive terms. Members are eligible for re-election after a 3-year interval. Elections will be arranged so that committee members resign in rotation.

8 . The committee shall meet at least once a year. In addition committee members may take decisions by correspondence. Each committee member shall have one vote. When necessary the chairman has a casting vote. A quorum of the committee shall be five members. Past chairmen may be invited to committee meetings.

9. The secretary of the study group shall submit annually, by the 1st of May of each year, a written summary of its activities and conclusions. This will be published in the volume of abstracts for the annual EASD meeting (and hence also in Diabetologia) with the agenda for the annual general assembly of EASD. An appointed committee member of DNSG shall be present during the general assembly to answer any questions of the published report. 
10. If so requested, the DNSG shall try to organise a symposium or workshop on a topic related to diabetes and nutrition during the annual EASD meeting.

11. The President of EASD, or his authorised deputy, shall be a member ex-officio of the DNSG and of its executive committee.

Approved at the businessmeeting of the Diabetes and Nutrition Study Group of the EASD during the 6th International Symposium on Diabetes and Nutrition, Espoo (SF), June 27-29, 1988.

\section{European Association for the Study of Diabetes, European Diabetes Epidemiology Study Group (EDEFSG)}

\author{
Officers: Chair: $\quad$ E. Eschwege, France \\ Vice Chair: D. Michaelis, GDR \\ Secretary: G.Sartor, Sweden \\ Treasurer:

$\begin{array}{ll}\text { Committee Members: } & \text { K.Pyörälä, Finland } \\ & \text { G. Crepaldi, Italy } \\ & \text { C.Arnold, Hungary }\end{array}$

Total Membership in Study Group: 55

Last Meeting: Venice, May 10-13,1990

Please see the 1989 report: Diabetologia, 1989, 32,452.

Next Meeting: May 20-23, 1989. Ein-Gedi Resort, Israel. Epidemiology of nephropathy, mortality and foot problems. Public health aspects of diabetes care.

Details available from: Professor Simon Weitzman

Ben Gurion University of the Negev

Diabetes Clinic

P.O.B. 653

Beer Sheva 84105

Israel

\section{European Association for the Study of Diabetes, Study Group control of Metabolism}

Officers: $\quad$ President: Prof. A. Tiengo (1990-1991)

President-elect: Dr. H.M.J.Krans (1992-1993)

Committee advisors: Drs. P.Ferré, K.Jungermann, H. M. J. Krans, J. P. Riou, E. van Schaftingen, J.Stanley, M.Sugden, A. Zorzano.

Total Membership in Study Group: 9

Last Meeting: Study Group Control of Metabolism

St.Thomas'Hospital, London

November 2-3, 1989

The Study Group Control of Metabolism was founded in May 1985 at the joint initiative of B. Jeanrenaud (who became President), J.Girard, L.Hue, Y.Le Marchand-Brustel, K.G.M.M.Alberti, R.M.Denton, F.A.Gries, E.Jéquier, A.Tiengo, W.K. Waldhäusl. The first meeting was held in Brussels (Novernber 20-21, 1987) and was organized by Drs. L.Hue and E.O.Balasse. The second one took place in Lyon (September 2-3, 1988) and was organized by Dr.J.P.Riou. The third meeting was held recently at St. Thomas' Hospital, London. It was excellently organized by Drs. Norman Palmer, Peter Sonksen and Mary Sugden. It started on November 2 by a lecture given by Jean Girard (Meudon) on the topic of the "Hormonal regulation of glucose and lipogenic enzyme gene expression during rat development". A meeting dinner followed. On November 3 , two poster sessions were organized and two lectures were given. One was presented by Dr. Robert Rizza (Rochester, USA) speaking on "The use of the isotope dilution technique to measure glucose production and utilization in diabetic and non-diabetic man: limitations and considerations". The other was given by Dr. Philip Cohen (Dundee) and was on the topic of "Okadaic acid, a new probe for studying the role of protein phosphorylation in the control of metabolism and other cellular processes".

The number of scientists attending was 148 , presenting 65 different posters of basic and clinical interest for the understanding of metabolism. A poster session chaired by Prof. R. Rizza and co-chaired by Prof. R.M. Denton was well attended. An obvious feature of the 1989 meeting was the considerable number of posters presenting data based upon molecular biology or molecular genetic approaches.

The format of the meeting adopted before proved again excellent. It aims at favoring interactions between basic and clinical researchers interested in the control of metabolism. To achieve this goal, in addition to the three lectures usually organized, all other reports are presented as posters, thereby permitting ample and informal discussions amongst participants.

The members of the Committee attending the meeting decided to renew the whole former Committee and to determine the location of the next two meetings. In keeping with the initial goal that the Study Group should be efficient but informal, it was decided that the President, always a member of the EASD, would also organize the Study Group meeting. He will remain in charge for two years, will help the President-elect and be helped himself in his task by several advisors who will be at the same time members of the Study Group Committee. They will be renewed in due time, following discussions within the Committee. Common sense will be applied upon selecting President, President-elect and Committee members with regard to representing various countries of Europe.

The 1990-1991 (January 1st 1990-December 31 1991) President will be Dr. A. Tiengo (Padova). The President-elect (1992-1993) will be Dr. H.M.J.Krans (The Netherlands). The Committee advisors will be Dr. P.Ferré (France), Dr. K.Jungermann (Germany), Dr. H. M.J. Krans (The Netherlands), Dr. J. P. Riou (France), Dr. E. van Schaftingen (Belgium), Dr. J.Stanley (Switzerland), Dr. M.Sugden (Great Britain), Dr. A.Zorzano (Spain).

In 1990, the Study Group meeting will be held, November 9-10, in Padova (Organizer Dr. A. Tiengo, colleagues and advisors). The 1991 Study Group meeting will be held in November (dates yet to be determined), in Leiden, (Organizers Dr. H.M.J.Krans, colleagues and advisors). These proposals met the approval of the Study Group scientists present at the General Session of November 3, 1989.

For suggestions, proposals, organizational matter concerning the November 9-10 1990 meeting in Padova, contact Prof. A. Tiengo, Universita Degli Studi Padova, Istituto Medicina Clinica, via N.Giustiniani, 35100 Padova, Italy. Tel. 0039498212335. Fax 0039498212260 .

This is the end of the report of the Study Group by the past-president who wishes to the Study Group a series of successful meetings in the years to come.

The fourth meeting of the EASD Study Group "Control of Metabolism" is scheduled in Padova (Italy) on Nov. 9.-10, 1990. The topics of the lectures will be: Brain energy fuels in hypoglycemia; Protein synthesis and degradation in vitro and in vivo; Glucose transporters and insulin action. Poster presentation is welcome (Deadline: Sept. 30, 1990). The deadline for registration for the meeting is August 31st, 1990. For further information write or phone to: Prof. Antonio Tiengo, Cattedra di Malattie del Ricambio, Policinico, Via Giustiniani 2, 35128 Padova, Italy. Phone n : 0039-498212335. Faxn ${ }^{\circ} 0039-49-8754179$.

\section{European Association for the Study of Diabetes, AIDSPIT}

$\begin{array}{cl}\text { Officers: Chair: } & \text { G.Pozza } \\ \text { Vice-Chair: } & \text { T.Deckert } \\ \text { Secretary: } & \text { P.Bratusch-Marrain } \\ \text { Treasurer: } & \text { R.Heine }\end{array}$




\section{Committee Members: $\quad$ C. Groth \\ C. Federlin \\ P. Micossi \\ Matthews \\ G. Tchobroutsky}

Total Membership in Study Group: no membership

Last Meeting: 9th Workshop

Jan 28-30, 1990

Igls/Austria

Pancreas Transplantation

Report from the transplant Registry. Clinical Indications for combined kidney and pancreas transplantation

Islet Transplantation

Progress in experimental and clinical islet transplantation. Islet transplantation in large animals

Intraperitoneal Insulin administration

Status of implantable pump work. Programmable pumps

Glucose sensors

Computers in diabetic care

Hypoglycaemia unawareness and human insulin

Next Meeting: 10th Workshop

Feb 3-5, 1991

Amsterdam, NL

Details available from: Robert Heine

Amsterdam, NL

\section{European Association for the Study of Diabetes, Diabetes Education Study Group}

$\begin{array}{cl}\text { Officers: Chair: } & \text { Dr. J. Day } \\ \text { Vice Chair: } & \text { Dr. A. Conti } \\ \text { Secretary: } & \text { Dr. D. Halimi } \\ \text { Treasurer: } & \text { Dr. A. Pernet }\end{array}$

The next meeting of our Study Group is a workshop to be held in Cambridge June 6th-10th 1990.

\section{Chairman's Report}

It is with pleasure that I provide a report on the year's activities of the Diabetes Study Group and its members. The programme has followed the principals laid down at the Windsor meeting and the last committee meeting. In particular we have attempted to capitalise on the main strength of the DESG, i. e. the workshop activity, since I think all are agreed that the reflective nature of interactive workshops can encourage and facilitate change in ways which no other form of postgraduate activities are capable. To this end we have planned a series of workshops involving four countries at a time, whose main aim is to develop a team from each country willing and able to initiate or encourage (where already established) a programme of educating the educators using workshop principals. To this end each workshop of a team of six to eight members, preferably multidisciplinary, are invited. The first of these meetings was held in May in Cambridge with teams from Finland, Switzerland, Greece and France. The first half of the four day workshop was devoted to the analysis of educational process and the second half, to the development of formal planning of actual national programmes. The results appeared very encouraging in that these countries produced very well defined workshop programmes with early starting dates. The fourth country had already gone a long way to developing a rather more extensive programme of education of carefully selected educators. This underwent considerable discussion and the differences in approach were most illuminating. Critical to the outcome of the workshop was the agreement of the principals of the Study Group to include some form of evaluation of the outcome of all our activities. All four countries agreed that we should undertake such an analysis a year or so after the programmes had started, to determine how successful these had been. This audit would include an assessment of whether the programme planned had actually commenced and some analysis of their success, i.e. had participants included in the team programme a check list of objectives, was it possible to discern a clear curriculum for insulin dependent and non-insulin dependent, were learner-centred methods used and what sort of evaluation was included. It was agreed that a second similar workshop, modified in the light of our Cambridge experience would be held in November and participants from Sweden, Eire, Italy and Spain have been invited. If the Cambridge success is repeated two similar workshops will then be planned for 1990 .

A third Eastern European workshop took place in Weimar with detailed discussions of progress and education in Eastern Europe to date and analysis of specific problems such as pregnancy, intensive insulin therapy and progress for the future. All present would have appreciated the progress that has been made in recent years and the enthusiasm for introducing new ideas in the light of the discussions at this workshop. The next East European workshop will take place in Czechoslovakia in 1991.

As suggested in the Windsor workshop, a small editorial board has been convened and the members met for a day and a half in Ipswich in April. The purpose was to undertake a review of the written material produced by the DESG including the teaching letters to determine whether new letters were required and if so, what form these should take. A full report of this meeting is attached. To summarise the outcome, we agreed that the teaching letter exercise using consensus workshop was a most valuable one. The topics that could be dealt with in this way had largely been covered. Some were recognised as now being out of date. Doubts were expressed as to how well these teaching letters were used however. We agreed therefore that additional information on a variety of topics would be helpful to members to complement these teaching letters, fill gaps and modify out of date material. It was agreed that this material could be produced in an attractive readable form which would involve the recipient. A list of topics is included in the full report, but we would welcome any suggestions of additions or deletions. It is proposed that these will be single author signed reviews of approximately 1500 2000 words, which will be fully referenced when appropriate. They will be mailed to the members with an invitation to the reader for comments. In addition, we have written to all the DESG members, trying to update our register to determine whether people listed are still active in the diabetes education field.

At the time of writing this report, the presentation of the activities of the diabetes education study group prior to the EASD meeting in Lisbon lies in the future. We are delighted to have this opportunity and have planned a programme which will allow full discussion of the workshop processes and their successes and failures, as well as a look at new aspects of diabetes education and in particular, the role of the nurse educator and consideration of the concept of health beliefs to our approach to diabetes education.

At the last meeting of the General Committee considerable discussion took place about the possibility of special sessions at, or in association with the EASD meeting, for those specifically interested in education, to encourage them to attend these meetings and allow a forum to meet colleagues from different countries. The DESG presentation in Lisbon would appear in part to fulfill this function for the Lisbon meeting. However, the paucity of papers and posters of an educational nature at this meeting appears very disappointing and representation has been made to try and rectify this for future meetings of the EASD and I hope to be able to report further progress to the Committee.

I would like to close by thanking you all for your help and support in the activities of the Study Group during this year and in particular for the invaluable help of my colleagues Dr. Halimi, Dr. Pernet and Dr. Conti. 